\title{
PENGEMBANGAN DESAIN WEB INTERAKTIF KULINER NUSANTARA BERBASIS KEARIFAN LOKAL KEDAERAHAN (STUDI KASUS KULINER KHAS KABUPATEN KUDUS)
}

\author{
Agus Setiawan $^{1 *}$, Henry Bastian ${ }^{2}$ \\ ${ }^{1}$ Program Studi Desain Komunikasi Visual Universitas Dian Nuswantoro \\ ${ }^{2}$,Program Studi Desain Komunikasi Visual Universitas Dian Nuswantoro \\ *agus.setiawan@dsn.dinus.ac.id
}

\begin{abstract}
Development of Interactive Archipelago Culinary Web Design Based on Local Wisdom of Regionalism (Case Study of Typical Culinary of Kudus Regency). This study seeks to inventory, describe and package local cultural values related to the typical Kudus culinary, as an ingredient to be further developed in a learning model and strengthening the creative economy of UMKM in Kudus Regency. How about interactive web media about Kudus special culinary to support the UMKM creative economy in Kudus Regency. So that they know and understand interactive web media about Kudus's unique culinary efforts to support the creative economy of UMKM in Kudus Regency. Contributions to making cultural values the main attraction in the creative culinary economy can be identified local cultural values in the culinary destination. With this study, the packaging of cultural values combined with a creative economy in the culinary field is expected to boost the tourism activities sector which has a positive impact on the social, economic and cultural fields. The research method uses more concrete qualitative methods looking at the aspects studied and expected outcomes. Outputs of the Study are Nusantara Culinary Interactive Web Media Based on Local Wisdom of the Region (Typical Culinary Case Study of Kudus Regency)
\end{abstract}

Key Words: Web Design, Culinary, Local Wisdom, Nusantara

\begin{abstract}
Abstrak: Pengembangan Desain Web Interaktif Kuliner Nusantara Berbasis Kearifan Lokal Kedaerahan (Studi Kasus Kuliner Khas Kabupaten Kudus). Penelitian ini berupaya menginventarisasi, mendeskripsikan, dan melakukan pengemasan nilai-nilai budaya lokal terkait dengan kuliner khas Kudus, sebagai bahan untuk dikembangkan lebih lanjut dalam sebuah model pembelajaran dan penguatan ekonomi kreatif UMKM di Kabupaten Kudus. Bagaimana media web Interaktif tentang kuliner khas Kudus dalam upaya menopang ekonomi kreatif UMKM di Kabupaten Kudus. Sehingga mengetahui dan memahami media web interaktif tentang kuliner khas Kudus dalam upaya menopang ekonomi kreatif UMKM di Kabupaten Kudus.

Kontribusi untuk menjadikan nilai-nilai budaya sebagai daya tarik utama dalam ekonomi kreatif kuliner dapat teridentifikasinya nilai-nilai budaya lokal yang ada pada daerah tujuan wisata kuliner. Dengan studi ini maka pengemasan nilai budaya yang dipadu dengan ekonomi kreatif dalam bidang kuliner diharapkan mendongkrak sector kegiatan kepariwisataan yang berdampak positif di bidang sosial, ekonomi, dan budaya. Metode penelitian menggunakan metode kualitatif yang lebih konkrit melihat aspek yang diteliti dan capaian luaran yang diharapkan. Luaran Penelitian yaitu Media Web Interaktif Kuliner Nusantara Berbasis Kearifan Lokal Kedaerahan (Studi Kasus Kuliner Khas Kabupaten Kudus)
\end{abstract}

Kata kunci: Desain Web, Kuliner, Kearifan lokal, Nusantara

\section{PENDAHULUAN}

Kudus merupakan satu dari semua kabupaten yang terletak di Jawa Tengah dengan luas wilayah paling kecil. Kabupaten Kudus berbatasan langsung dengan Kabupaten Pati di sebelah timur, Kabupaten Demak dan Kabupaten Purwodadi di sebelah selatan dan berbatasan langsung dengan Kabupaten Jepara di sebelah barat dan utara. Menurut para sejarawan, Kota Kudus dahulu berasal dari sebuah desa kecil di tepi Sungai Gelis yang bernama Desa Tajug (Salam 1995:5). Keterkaitan dengan sungai Gelis, Ashadi menungkapkan, bahwa Kota Kudus dibangun selama akhir abad ke-XVIII M hingga awal abad ke-XIX M di lokasi baru, lebih kurang 1 $\mathrm{km}$ ke arah timur pusat kota lama, menyeberangi sungai Gelis (Ashadi 2010:150). Adapun kota Kudus berdasarkan temuan inskripsi di atas mimbar masjid Menara Kudus. Dan hanya Kuduslah satu-satunya kota yang ada di seluruh nusantara yang berasal dari bahasa Arab yaitu Al-Quds yang berarti suci (Ashadi 2010:150).

Kudus adalah daerah yang kaya akan situs sejarah dan budaya (Indrahti, Maziyah, and Alamsyah 2018:88). Keberadaan situs sejarah dan budaya juga menguatkan dari sisi potensi 
alam. Kepala Bidang Pariwisata Sri Wahyuningsih menuturkan bahwa perkembangan pariwisata di Kudus setiap tahun mengalami peningkatan yang bagus dan kini sektor pariwisata tidak hanya didominasi obyek wisata religi saja, melainkan pariwisata non religi pun saat ini mulai tumbuh dan bahkan ini bisa berkembang menjadi ikon baru pariwisata di Kudus. Potensi yang dimunculkan tersebut memang rata - rata dari potensi alam yang ada di sejumlah desa di Kudus, dan tentunya ini menambah daftar obyek wisata yang ada di Kudus utamanya yang non religi. "Pihaknya optimis apabila dikelola secara profesional akan berkembang dengan baik," harapnya. Wisata religi masih mendominasi di Kudus, yakni sekitar 700 800 orang wisatawan, sedangkan untuk non religi hanya sekitar $400-500$ orang. Memang ini bukan pekerjaan yang mudah, untuk mewujudkannya perlu pengelolaan yang baik (Sofiyanto 2018b).

Upaya mendukung pariwisata, Gunawan selaku tenaga ahli Bidang Periklanan Branding dan Komunikasi Digital mengatakan media digital dapat menumbuhkan daya tarik pariwisata akibat adanya akses informasi yang mudah diperoleh lewat media sosial. "Perkembangan teknologi yang sangat pesat mempengaruhi gaya hidup dan pola pikir manusia dalam kehidupannya sehari-hari," Kemajuan teknologi masa kin, lanjutnya, telah mengubah secara keseluruhan industri pariwisata melalui media digital. Dalam beberapa tahun terakhir, media digital telah berkontribusi dalam mempromosikan tujuan atau objek wisata. Media mempunyai peranan krusial dalam pertumbuhan dan kemajuan pariwisata, salah satunya dengan menyampaikan informasi secara mendalam tentang objek-objek wisata yang dibutuhkan oleh turis domestik maupun mancanegara (Sofiyanto 2018a).

Berangkat dari hal di atas, maka penciptaan desain web interaktif dianggap berkontribusi karena belum ada media secara konperenship tentang kuliner khas Kudus berbasis kearifal lokal kedaerahan yang memberikan informasi secara lengkap khususnya yang membahas mengenai asal-usul atau mitos, bahan baku, keistimewaan dan cara sajian semua dikemas jadi satu kesatuan wadah informasi yang lengkap. Sudut pandang budaya menjadi point penting dalam perumusan konsep perancangan desain web tentang kuliner nusantara. Sepanjang pengamatan sendiri hingga saat ini belum pernah desain web interaktif yang yang berbasis kearifal lokal. Sedangkan pada media internet sendiri banyak dikemukakan makanan apa saja yang merupakan khas dari Kabupaten Kudus tetapi tidak dibahas secara lengkap, misal mengenai lokasi atau alamat tempat penjual makanan khas Kabupaten Kudus yang enak dan asli dari Kabupaten Kudus, bahkan dari sudut pandang budaya.

Penelitian ini berupaya

menginventarisasi, mendeskripsikan, dan melakukan pengemasan nilai-nilai budaya lokal terkait dengan kuliner khas Kudus, sebagai bahan untuk dikembangkan lebih lanjut dalam sebuah model pembelajaran dan penguatan ekonomi kreatif UMKM di Kabupaten Kudus. Dengan studi ini maka pengemasan nilai budaya yang dipadu dengan ekonomi kreatif dalam bidang kuliner diharapkan mendongkrak sector kegiatan kepariwisataan yang berdampak positif di bidang sosial, ekonomi, dan budaya.

Kontribusi untuk menjadikan nilainilai budaya sebagai daya tarik utama dalam ekonomi kreatif kuliner dapat teridentifikasinya nilai-nilai budaya lokal yang ada pada daerah tujuan wisata kuliner. Terutama lebih mengedepankan pada kearifan lokal dengan tetap memberdayakan masyarakat sebagai subyek dalam industri wisata kuliner. Kedua, diperolehnya model pengembangan ekomomi kreatif kuliner melalui pengemasan nilai-nilai budaya lokal, setelah melalui kesepakatan dengan pendukung budaya itu sendiri dan disesuaikan dengan pemakai budaya sebagai pengunjung wisata kuliner. Proses berikutnya adalah berimbas pada peningkatan ekonomi masyarakat sebagai bendukung budaya maupun sekaligus sebagai pelaku wisata. Keempat, dari segi ekonomi dapat dimanfaatkan sebagai pertimbangan dalam penentuan langkahlangkah pengembangan pariwisata pada daerah tujuan wisata kuliner di kabupaten Kudus dan di Indonesia pada umumnya. Pentingnya kearifan lokal yang dikemas dalam bingkai teknologi sehingga perlu diciptakan media web Interaktif tentang kuliner khas Kudus dalam upaya menopang 
ekonomi kreatif UMKM di Kabupaten Kudus. Daya dukung yang signifikan, dengan tujuan menciptakan media web interaktif kuliner nusantara berbasis kearifan lokal kedaerahan (studi kasus kuliner khas Kabupaten Kudus).

\section{METODE PENELITIAN}

Penelitian ini adalah penelitian yang bersifat deskriptif. Menurut Sekaran (2010: 105-106) penelitian deskriptif adalah penelitian yang dilakukan untuk memastikan dan memampukan peneliti untuk menggambarkan karakteristik dari variablevariabel yang menjadi perhatian pada suatu situasi. Tujuan dari penelitian dekriptif adalah untuk mendapatkan suatu profil atau gambaran yang lengkap dari aspek-aspek relevan mengenai sebuah gejala yang menarik, yang terjadi pada suatu individu, organisasi, industri, atau hal-hal lainnya. Terkait dengan paparan mengenai metode penelitian deskriptif di atas, maka metode deskriptif dipilih karena pada studi ini dilakukan upaya-upaya untuk mendapatkan profil lengkap dari potensi kuliner khas Kudus, yang selanjutnya digunakan untuk membuat sebuah model wisata kreatif. Secara lebih rinci, kegiatankegiatan yang diajukan adalah: 1. Melakukan identifikasi terhadap lingkungan internal dan eksternal tentang kuliner khas Kudus. 2. Melakukan identifikasi terhadap kajian awal terkait informasi dasar mengenai kuliner kas Kudus; yang meliputi: atraksi, transportasi intra dan antar daerah, infrastruktur, fasilitas dan layanan, event/festival dan aktivitas wisata. 3. Melakukan identifikasi terhadap Baur Pemasaran dari destinasi wisata kuliner Kabupaten Kudus. 4. Menyusun sebuah model destinasi pariwisata kreatif bagi Kabupaten Kudus. 5. Menciptakan Web Interaktif kulner khas Kudus kerjasama dengan Pemerintah Kabupaten Kudus,

Sehingga dapat dilihat secara garis besar bagan penelitian secara utuh dalam pentahapannya dalam tabel di bawah ini:

Tabel 1. Pentahapan penelitian

\begin{tabular}{ccc}
\hline $\begin{array}{c}\text { Aspek yang } \\
\text { diteliti }\end{array}$ & Alur & $\begin{array}{c}\text { Target luaran } \\
\text { yang dicapai }\end{array}$ \\
\hline
\end{tabular}

\begin{tabular}{ll}
\hline $\begin{array}{l}\text { Kuliner Khas } \\
\text { Kudus }\end{array}$ & $\begin{array}{l}\text { Identifikasi } \\
\text { jenis makanan } \\
\text { dan oleh-oleh } \\
\text { kas Kudus }\end{array}$ \\
\hline $\begin{array}{l}\text { Makanan dan } \\
\text { oleh-oleh khas } \\
\text { Kudus }\end{array}$ & $\begin{array}{l}\text { Ditemukan } \\
\text { sejarah dan } \\
\text { kearifan lokal }\end{array}$ \\
\hline Pengembagan & 1. $\begin{array}{l}\text { Ditemukan } \\
\text { media }\end{array}$ \\
Media web & sebagai \\
Interaktif & media \\
& literasi \\
tenntang & kuliner khas \\
& Kudus \\
& 2. $\begin{array}{l}\text { Ditemukan } \\
\text { kearifan }\end{array}$ \\
& lokal dalam \\
kuliner khas & Kudus \\
\hline
\end{tabular}

Hasil yang dicapai dari penelitian

Desain web interaktif kuliner nusantara

berbasis kearifan lokal kedaerahan

\section{HASIL DAN PEMBAHASAN \\ 1. Sekilah Kabupaten Kudus \\ a) Sejarah Kota Kudus}

Sejarah Kota Kudus tidak terlepas dari Sunan Kudus. Karena keahlian dan ilmunya, maka Sunan Kudus diberi tugas memimpin para Jamaah Haji, sehingga beliau mendapat gelar "Amir Haji" yang artinya orang yang menguasai urusan para Jama'ah Haji. Beliau pernah menetap di Baitul Maqdis untuk belajar agama Islam. Ketika itu disana sedang berjangkit wabah penyakit, sehingga banyak orang yang mati. Berkat usaha Ja'far Shoddiq, wabah tersebut dapat diberantas. Atas jasajasanya, maka Amir di Palestina memberikan hadiah berupa Ijazah Wilayah, yaitu pemberian wewenang menguasai suatu daerah di Palestina. Pemberian wewenang tersebut tertulis pada batu yang ditulis dengan huruf arab kuno, dan sekarang masih utuh terdapat di atas Mihrab Masjid Menara Kudus (Diskominfo 2017).

Sunan Kudus memohon kepada Amir Palestina yang sekaligus sebagai gurunya 
untuk memindahkan wewenang wilayah tersebut ke pulau Jawa. Permohonan tersebut dapat disetujui dan Ja'far Shoddiq pulang ke Jawa. Setelah pulang, Ja'far Shoddiq mendirikan Masjid di daerah Kudus pada tahun $1956 \mathrm{H}$ atau $1548 \mathrm{M}$. Semula diberi nama Al Manar atau Masjid Al Aqsho, meniru nama Masjid di Yerussalem yang bernama Masjidil Aqsho. Kota Yerussalem juga disebut Baitul Maqdis atau Al-Quds. Dari kata Al-Quds tersebut kemudian lahir kata Kudus, yang kemudian digunakan untuk nama kota Kudus sekarang. Sebelumnya mungkin bernama Loaram, dan nama ini masih dipakai sebagai nama Desa Loram sampai sekarang. Masjid buatan Sunan Kudus tersebut dikenal dengan nama masjid Menara di Kauman Kulon. Sejak Sunan Kudus bertempat tinggal di daerah itu, jumlah kaum muslimin makin bertambah sehingga daerah disekitar Masjid diberi nama Kauman, yang berarti tempat tinggal kaum muslimin (Diskominfo 2017).

Ada cerita rakyat di Kudus tentang 'apa sebab masyarakat Kudus sampai sekarang tidak menyembelih sapi'?. Sebelum kedatangan Islam, daerah Kudus dan sekitarnya merupakan Pusat Agama Hindu. Dahulu Sunan Kudus ketika dahaga pernah ditolong oleh seorang pendeta Hindu dengan diberi air susu sapi. Maka sebagai rasa terima kasih, Sunan Kudus waktu itu melarang menyembelih binatang sapi dimana dalam agama Hindu, sapi merupakan hewan yang dimuliakan (Diskominfo 2017).

Hari Jadi Kota Kudus di tetapkan pada tanggal 23 September $1549 \mathrm{M}$ dan diatur dalam Peraturan Daerah (PERDA) No. 11 tahun 1990 tentang Hari Jadi Kudus yang di terbitkan tanggal 6 Juli 1990 yaitu pada era Bupati Kolonel Soedarsono. Hari jadi Kota Kudus dirayakan dengan parade, upacara, tasyakuran dan beberapa kegiatan di Al Aqsa / Masjid Menara yang dilanjutkan dengan ritual keagamaan seperti doa bersama dan tahlil (Diskominfo 2017).

\section{b) Kudus Sebagai Kota Kretek}

Karena Kudus terdapat banyak pabrik rokok di antaranya: Djarum, Sukun, Jambu Bol, dan lainnya. Bahkan jumlah warga lokal yang kerja di pabrik rokok amat fantastis (Hazami 2016). Berangkat dari keberadaan pabrik rokok di Kudus sehingga terdapat ungkapan yang khas yaitu kota kretek. Sebutan kota kretek juga mendorong terpailah dalan kontek budaya yaitu munculnya tari kretek dan museum kretek.

Tari kretek merupakan sebuah tari yang menceritakan para buruh rokok yang sedang bekerja membuat rokok, mulai dari pemilihan tembakau hingga rokok siap dipasarkan.Awalnya tari Kretek bernama tari Mbatil. Namun, karena nama mbatil tidak begitu dikenal di masyarakat, digantilah dengan tari Kretek (Mulanto, 2014, p.2).

Tari Kretek bentuk kesenian yang lebih pada upaya ekplorasi budaya kretek yang sudah menjadi idiom di kabupaten kudus sehungga sejarah rokok kretek dalam pergumulan zaman akhirnya memuarakan pula pada seni pertunjukan, yaitu Tari Kretek. Sumber idenya yg bermuasal dari budaya kretek, sehingga gerak dalam tarian yang dimainkan oleh khususnya perempuan penari menggunakan kostum pakaian adat Kudus dengan caping kalo serta selendang tohwatu menggambarkan proses pelintingan rokok kretek (Disbudpar n.d.). Dengan kata lain, tari Kretek merupakan profil Kabupaten Kudus, yang merepresentasikan keberadaan Kabupaten Kudus sebagai kota Kretek.

Museum Kretek merupakan Museum Persembahan Persatuan Perusahaan Rokok Kudus (PPRK) yang diresmikan oleh Gubernur Jawa Tengah Soeparjo Rustam pada 3 Oktober 1986 ini, berlokasi di Desa Getas Pejaten, Kecamatan Jati, sekitar 1,5 km selatan pusat Kota Kudus. Kehadiran museum kretek juga tak terlepas dari budaya kretek yang lebih menekankan pada inventarisasi bahan dan alat pembuatan rokok dari masa ke masa.

\section{c) Kudus dan budaya}

Kudus adalah daerah yang kaya akan situs sejarah dan budaya. Sebagai tempat bersejarah, khususnya berkaitan dengan persebaran agama Islam, Kudus memiliki beberapa tokoh agama yang hingga saat ini masih diyakini kharismanya oleh masyarakat sekitar. Tokohtokoh tersebut antara lain adalah Sunan Kudus, Sunan Muria, Kyai Telingsing, Mbah Kyai Dudo, dan, Eyang Buyut Sakri. Makam kelima tokoh yang berkaitan dengan persebaran agama Islam di Kudus pada sekitar abad ke-16 itu masing-masing memiliki tradisi budaya 
yang berbeda berkaitan dengan ketokohannya (Indrahti et al. 2018:88).

\section{Kuliner Khas Kudus dan kearifan lokalnya}

a) Nasi jangkrik

Menurut Said penjual nasi Jangkrik, bahwa nama jangrik diawali sejak zaman dulu, wali yang dipanggil Kiai Telingsing bersama Sunan Kudus, serta wali lainnya berkumpul di bangunan tajug Menara Kudus. "Istri Sunan Kudus saat itu memasak sebuah menu. Ternyata menu itu disuguhkan ke para hadirin yang ada di bangunan tajug. Di saat menyantap menu, ada yang menyeletuk kata jangkrik, masakan opo iki, kok enake pol' (Hazami, 2019, p.1). Celetukan yang memuji betapa enaknya rasa menu itu," kata Said menuturkan sejarah yang diketahuinya.

Menurut Ketua Yayasan Masjid Menara Makam Sunan Kudus, M. Nadjib Hassan, nasi jangkrik merupakan makanan khas Kudus yang konon merupakan makanan kegemaran Sunan Kudus. Nasi jangkrik dibagikan setiap tanggal 10 Muharam sejak Sunan Kudus masih hidup hingga kini. Tahun ini pihak Yayasan memasak sebanyak 6,1 ton beras, 73 ekor kambing dan 11 ekor kerbau. Bahan-bahan itu dikumpul dan pihak yayasan membuat sebanyak 26.000 nasi bungkus jangkrik. Dari sini, nasi jangkrik dipercaya menjadi sarana agar tanamannya tidak dimakan hama penyakit. Di samping itu, lanjutnya, nasi kering tersebut biasanya bisa juga digunakan sebagai campuran minum obat yang bisa menyembuhkan. Selain digunakan untuk melengkapi ritual bukak luwur, nasi jangkrik ini juga digunakan sebagai slametan nadzar atas terkabulnya permohonan peziarah di Makam Sunan Kudus ini. Ketika penelitian di lapangan sedang berlangsung, kami mendapati salah satu peziarah yang menyerahkan nasi jangkrik ini kepada punggawa Makam Sunan Kudus sebagai ungkapan rasa syukurnya atas terkabulnya permohonannya.

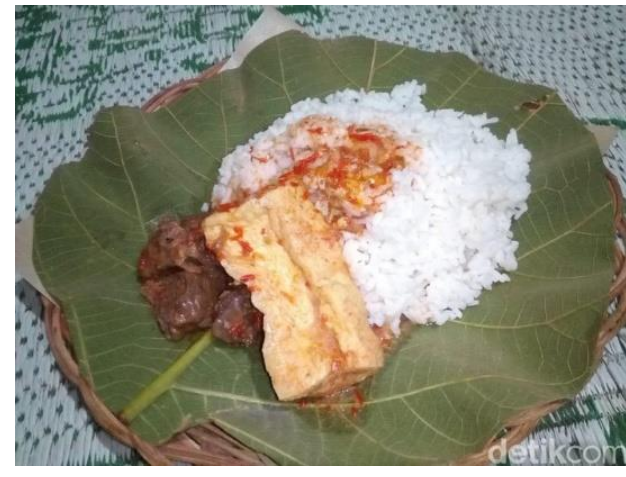

Gambar 1. Sajian nasi jangkrik di atas daun jati

Sumber: (Hazami 2019:1)

\section{b) Sate kerbau}

Penyair Kudus Thomas Budi Santoso, melihat dalam setiap kerat daging kerbau yang disantap warga Kudus terdapat nilai-nilai toleransi yang diwariskan sejak masa Sunan Kudus hingga kini. Dalam menyebarkan agama Islam, Sunan Kudus tetap memelihara nilai-nilai lokal yang dianut oleh masyarakat. Sekitar abad ke-16, wilayah Kudus bagian dari Kerajaan Majapahit yang sudah menganut Hindu dan Buddha. "Warga Hindu tidak mengonsumsi daging sapi. Sunan juga meminta menghormati kebiasaan itu," kata Budi Santoso (Auliani, 2014:1). Kearifan lokal yang terus tergaungkan dari sate kerbau yaitu selalu terceritakan tentang toleransi.

Indriani mengungkapkan, bahwa pada zaman dahulu masyarakat di sekitar area kota Kudus banyak menganut agama Hindu dan sapi merupakan hewan suci yang tidak boleh disembelih maupun dimakan bagi penganut agama tersebut. Ketika masuknya Islam di kota ini yang disebarkan oleh Sunan Kudus, ia melarang pengikutnya untuk menyembelihan dan mengonsumsi sapi pada saat Hari Raya Idul Adha untuk menghormati pemeluk Agama Hindu dan menggantinya dengan kerbau. Sejak saat itu olahan daging kerbau bermunculan, salah satunya adalah Sate Kerbau yang menjadi kuliner khas kota Kudus. Hal ini merupakan salah satu simbol toleransi antar umat Beragama pada waktu itu (indriani, 2018:1). 


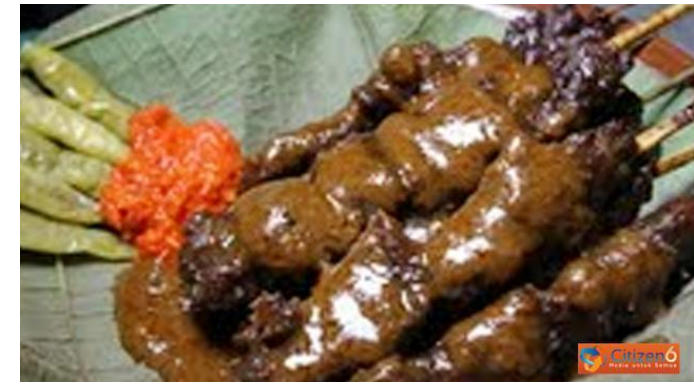

Gambar 2. Sajian sate kerbau khas kudus Sumber: (rahmayantie. Erieke Nindha 2012)

\section{c) Semur Kuthuk}

Semur kutuk adalah jenis masakan yang terbilang mudah dijumpai di wilayah kabupaten Kudus. Meski tidak semua warung menyediakannya, namun masyarakat seolah sudah paham mau kemana ketika ingin menikmati semur kutuk ini. Sebut saja di kawasan Jekulo, ada beberapa warung yang memang khusus menjual masakan ikan ini. Kemudian juga yang terkenal adalah di Desa Pelang, Kandangmas, dan sekitarnya, yang ada di Kecamatan Dawe. Beberapa warung yang ada di sepanjang jalan desa itu, bisa dipastikan menjual semur kutuk. Sebuah nilai lebih yang akan membawa Anda menikmati sajian yang tidak biasa. Masakan semur kutuk seolah menjadi masakan otentik milik Kabupaten Kudus. Warung-warung makan sederhana di Kudus, biasanya menyediakan semur ini, untuk melengkapi aneka masakan atau menu lainnya. Pertanyaan dari pengunjung apakah ada semur kutuk, biasanya akan melengkapi pertanyaan soal nama-nama menu yang disediakan.(Merie 2015:1)

\section{d) Lentog Tanjung}

Lentog Tanjung merupakan makanan dengan cara penyajian terdiri dari lontong, sayur gori (nangka muda), kotokan tahu dengan tambahan bawang goreng dan sambal diatasnya. Makanan ini sering disajikan menjadi menu sarapan masyarakat Kudus, utamanya pada akhir pekan. Menurut cerita, keberadaan makanan tradisional ini berkaitan erat dengan masa awal penyebaran Islam di daerah Kudus. Tepatnya pada zaman masuknya walisongo. "Ceritanya, dahulu ada seorang Wali yang hendak membangun sebuah padepokan di daerah Tanjungkarang. Di tengah proses pembangunan padepokan tersebut, Sang Wali mendengar suara 'tog-togtog' seperti orang yang sedang memasak nasi," kata Kepala Desa Tanjungkarang, Sumarno, Selasa (03-07-2018). Karena terganggu suara tersebut, lenjutnya, Sang Wali menghentikan proses pembuatan padepokan. Wali tersebut kemudian bersabda "Rejoning zaman, wong daerah kene yen dodol sego ora payu" yang artinya, nantinya orang daerah sini jika berjualan nasi tidak akan laku. Dari sabda tersebut, masyarakat kemudian berupaya membuat makanan pengganti nasi. Dengan berbagai bahan makanan lokal, beras dikemas menjadi sebuah makanan yang berbeda namun tetap lezat. Higga terciptalah makanan yang diberi nama lentog.(Chusna 2018:1)

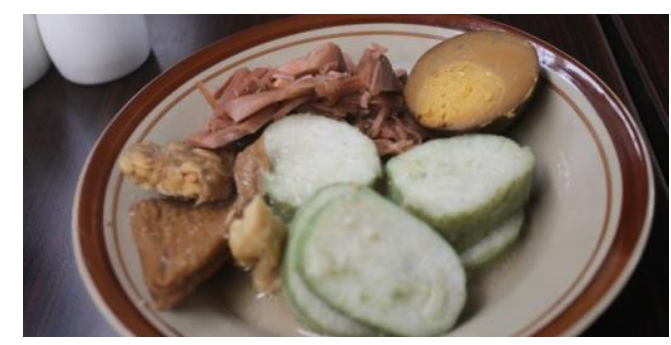

Gambar 3. Sajian nasi lentog tanjung Sumber: (Nurdin 2015)

\section{Pengembangan Desain Web}

\section{a) Layout Desain Web}

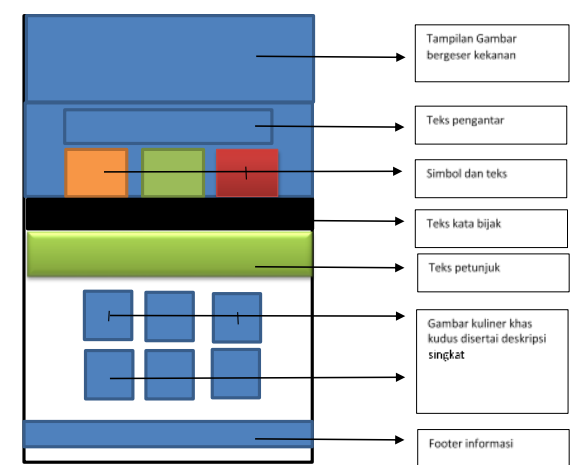

Gambar 4. Rancangan Layout Desain Web

\section{b) Tampilan Desain awal Web Interaktif}

Tampilan utama web ini menunjukkan tampilan gambar kuliner khas kudus diselingi dengan gambar bernuansa kehidupan masyarakat lampau dalam bingkai tradisi. Di atas gambar ditempelkan tombol menu di antaranya welcome, kuliner, dokumen, dan 
disclamer. Adapun peran tombol menu tersebut dijelaskan sebagai berikut:

1) Welcome sebuah link menu yang digunakan untuk menuju halaman awal.

2) Kuliner sebuah link yang digunakan untuk mengetahui berbagai kuliner khas Kudus.

3) Dokumen merupakan sebuah link yang berisi tentang liputan hal unik tentang kuliner khas kudus.

4) Disclaimer merupakan sebuah link yang diperuntukkan untuk memberikan keterangan mengenai penolakan copyright semua isi dari web tersebut baik berupa gambar dan tulisan.

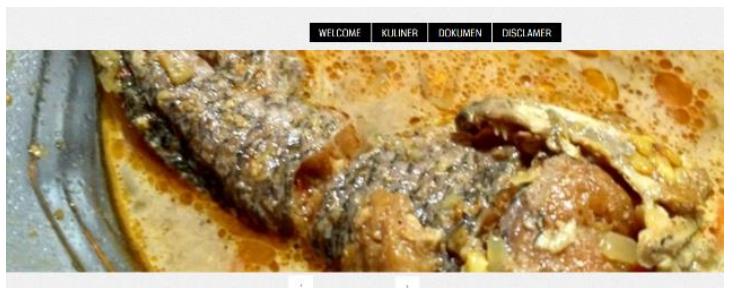

Gambar 5 Tampilan Gambar bergeser kekanan

Tampilan awal selanjutnya mengarahkan pada tampilan yang bertuliskan "Sugeng Rawuh". Tulisan sugeng rawuh ini dimaksudkan untuk mengantarkan seseorang untuk mengetahui tentang web ini. Berikut deskripsi yang tertulis pada tampilan web.

"Selamat Datang di website / laman ini, di
tujukan untuk mengenalkan potensi wisata
kuliner kota kudus yang sangat menarik ,
sekaligus sebagai informasi di dunia maya
tentang kekayaan warisan nenek moyang
berupa makanan / kuliner yang patut
semestinya kita lestarikan. Kuliner merupakan
salah satu hal yang biasanya paling dicari
ketika kita berkunjung ke suatu tempat. Cita
rasa yang ditawarkan biasanya berbeda.
Sehingga setiap tempat memiliki penyajian
makanan yang unik dengan rasa yang menarik.
Namun selain itu, wisata kuliner juga
merupakan salah satu yang menarik pada suatu
kota atau daerah. Seperti halnya di daerah
Kudus ini. Ada beberapa makanan khas yang
bisa anda coba dengan cita rasa yang mungkin
belum pernah anda cicipi sebelumnya. Untuk
itulah, sebelum berkunjung ke kota Kudus.
Maka anda perlu untuk mengetahui makanan
khas apa saja yang enak untuk dicicipi dan
dicoba di daerah Kudus ini"

Selanjutnya, seorang pengamat atau peningkmat diajak untuk mengenali lebih jauh tentang kuliner khas Kudus sehingga perlu ditambahkan dengan simbol dan tulisan yaitu gambar kursor dan tulisan "apa saja", gambar love dan "Unik", gambar bintang dan tulisan "rekomendasi". Perancangan simbol demikian untuk memicu daya pikir seseorang dalam konteks ke rasa ingin tahu yang lebih.

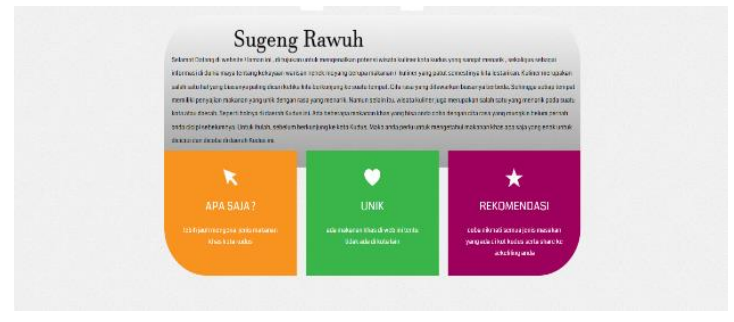

Gambar 6 tampilan tek pengantar dan Simbol serta teks

Seperti filosofi ketika orang makan mengenal 3 langkah mudah yaitu upaya melihat sesuatu lebih dalam proses pengenalan, sehingga interaksi penegenalan sebagai tahap awal sebelum mencintai dan dinikmati. Mencintai dalam artian apa yang dimiliki dalam warisan budaya perlu diupayakan tetap bertahan dan dinikmati dalam artian terjadinya interaksi dalam pendalaman cita rasa kedaerahan.

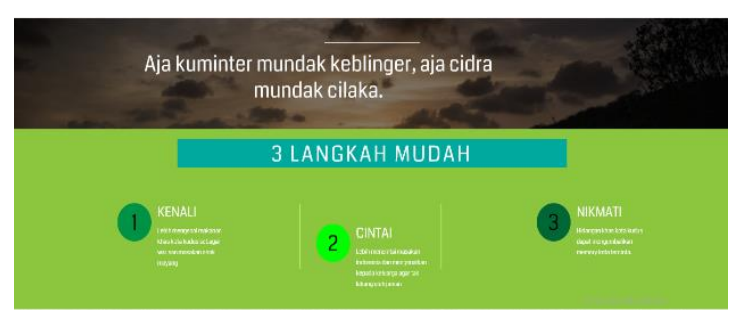

Gambar 7 Tampilan Teks kata bijak dan teks petunjuk

Tahap selanjutnya adalah visualisasi berbagai macam kuliner berkonsep nusantara yaitu penyajian yang lebih menekankan pada kekhasan daerah setempat, dalam hal ini adalah kuliner khas Kudus di antaranya sate kerbau, soto kerbau, garang asam, nasi jangkrik, dan semur khutuk. Visualisasi kuliner khas kudus didukung dengan deskripsi mengenai ceritacerita dibalik kebertahanan jenis makanan tersebut dan peta lokasi keberadaan jenis usaha yang menjual kuliner khas kudus. 


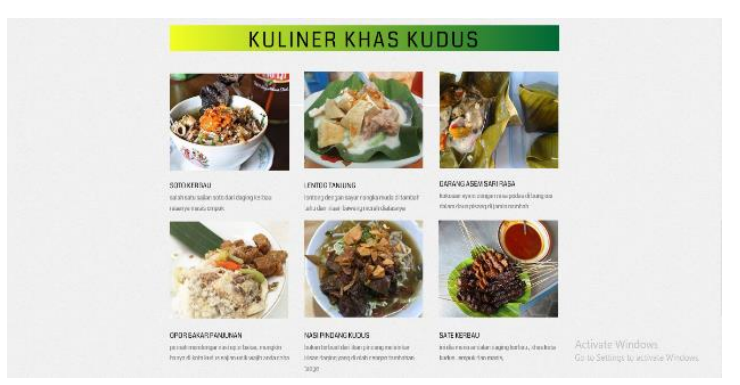

Gambar 8 tampilan berbagai gambar kuliner khas Kudus

\section{a}

\section{$\theta=(1)=$}

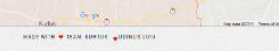

Gambar 9 Tampilan footer informasi

\section{PENUTUP}

Penelitian ini berupaya menginventarisasi, mendeskripsikan, dan melakukan pengemasan nilai-nilai budaya lokal terkait dengan kuliner khas Kudus, Sudut pandang budaya menjadi point penting dalam perumusan konsep perancangan desain web tentang kuliner nusantara. Sepanjang pengamatan sendiri hingga saat ini belum pernah desain web interaktif yang yang berbasis kearifal lokal.

Kontribusi untuk menjadikan nilainilai budaya sebagai daya tarik utama dalam ekonomi kreatif kuliner dapat teridentifikasinya nilai-nilai budaya lokal yang ada pada daerah tujuan wisata kuliner. Terutama lebih mengedepankan pada kearifan lokal dengan tetap memberdayakan masyarakat sebagai subyek dalam industri wisata kuliner. Kedua, diperolehnya model pengembangan ekomomi kreatif kuliner melalui pengemasan nilai-nilai budaya lokal, setelah melalui kesepakatan dengan pendukung budaya itu sendiri dan disesuaikan dengan pemakai budaya sebagai pengunjung wisata kuliner.

\section{UCAPAN TERIMA KASIH}

Penulis berterima kasih kepada LPPM Universitas Dian Nuswantoro yang sudah membantu terselesainya artikel ini. Tidak lupa juga kami ucapkan terima kasih kepada pemerintah Kabupaten Kudus, Dinas kebudayaan dan Pariwisata yang sudah memberikan akses dalam penelitian. Semua pihak yang tidak bisa kami sebutkan satu persatu. Kami yakin tulisan ini kurang dari sempurna, maka saran dan kritik yang membangun kami harapkan.

\section{DAFTAR PUSTAKA}

Ashadi, Ashadi. 2010. "Jejak Keberadaan Rumah Tradisional Kudus: Sebuah Kajian Antropologi - Arsitektur Dan Sejarah." NALARs 9(2).

Auliani, Palupi Annisa. 2014. "Santapan Daging Kerbau Dan Jejak Toleransi Di Kota Kudus - Semua Halaman Nationalgeographic.Grid.Id." Nationalgeographic.Grid.ID 1.

Chusna, Nila Niswatul. 2018. "Alasan, Mengapa Makanan Ini Dinamakan Lentog." ISKNEWS.COM 1.

Disbudpar. n.d. "Wisata Kuliner DISBUDPAR-KUDUS." Retrieved July 10, 2019 (https://disbudparkudus.weebly.com/wis ata-kuliner.html).

Diskominfo. 2017. "Profil Kabupaten Kudus | Pemerintah Kabupaten Kudus." Diskominfo Pemerintah Kabupaten Kudus 1.

Hazami, Akrom. 2016. "5 Julukan Kota Kudus Yang Unik Dan Menarik | MuriaNewsCom." MuriaNewsCom 1.

Hazami, Akrom. 2019. "Nasi Jangkrik, Racikan Nasi Kesukaan Sunan Kudus Yang Nikmat Gurihnya." Detikfood 1.

Indrahti, Sri, Siti Maziyah, and Alamsyah Alamsyah. 2018. "Makna Simbolis Dan Filosofis Kuliner Tradisional Pada Upacara Tradisi Di Kudus." Endogami: Jurnal Ilmiah Kajian Antropologi 2(1):88.

indriani, ririn. 2018. "Menelusuri Sejarah Sate Kerbau, Simbol Toleransi Di Kota Kudus." Suara.Com 1.

Merie. 2015. "Kudus Dan Signature Dish Bernama Semur Kutuk | Koran Muria." Koranmuria 1.

Mulanto, Joko. 2014. "Pewarisan Bentuk, Nilai, Dan Makna Tari Kretek." Jurnal Seni Tari 3(2). 
Nurdin, Nazar. 2015. "Bingung Sarapan Apa Di Kudus? Cobalah Lentog Tanjung." Kompas.Com 1.

rahmayantie. Erieke Nindha. 2012. "Sate Kerbau, Kuliner Unik Kota Kretek Citizen6 Liputan6.Com." Liputan6.Com 1.

Salam, Solichin. 1995. Kudus Selayang Pandang. Kudus: Gema Salam.

Sofiyanto, Aris. 2018a. "Kemenpar Ajak Pegiat Media Sosial Di Kudus Promosikan Wisata Kota Kretek ISKNEWS.COM." ISKNEWS.COM 1.

Sofiyanto, Aris. 2018b. "Sektor Pariwisata Kudus Selain Religi Terus Digenjot." ISKNEWS.COM 1. 